\title{
Finite Element Simulation of the Deformation of a Cell Driven by Creeping Flow
}

\author{
F. Serrano Alcalde ${ }^{1}$, J.M. García-Aznar ${ }^{1}$, MJ Gómez-Benito ${ }^{1}$ \\ ${ }^{1}$ M2BE, Instituto de Investigación en Ingeniería de Aragón (I3A) \\ Universidad de Zaragoza, Mariano Esquillor s/n, 50018, Zaragoza, Spain. \\ Tel.+34-976762707, e-mail:jmgaraz@unizar.es
}

\begin{abstract}
The purpose of this work is to calculate the deformation undergone by a cell in function of its nucleus size and mechanical properties. The cell immersed in a fluid go through a variable section channel and it is deformed by fluid forces.

Cell deformation into the channel causes changes at the fluid velocity profile. This fluid configuration change results in diferent normal and viscous forces around the cell. Due to strong correlation between cell deformation and fluid velocity profile, a fluidsolid interacción (FSI) is required.
\end{abstract}

\section{Material and Methods}

The aim of this work is to develop a numerical simulation of a real-time deformability cytometry. An experimental method to stimate the mechanical properties of specific cells has been simulated.

\section{Modeling Cell material}

Cells used for simulations were HL-60 (human promyellocytic leukemia cells) [1,2]. The cell nucleus and cytoplasm are assumed to behave as a solid, where its assumed constituve behaviour is hyperelastic.

\section{Fluid-solid interaction}

The model has been simulated using the finite element method in the commercial program ABAQUS, in which a Coupled Eulerian-Lagrangian (CEL) analysis has been carried out. An Eulerian mesh is assigned to the fluid, in which material is allowed to flow across element boundaries in a rigid mesh. On the other hand, a Lagrangian mesh is assigned to the cell, where material is closely associated with an element and the material moves only with the deformation of the mesh. The undeformed cell configurartion (figure 1) and the deformed one (figure 2) are compared against experimental configuration $[1,2]$ to determine the most adecuate set of mechanical properties which characterize the cell $[1,2]$.

\section{Conclusions}

Using computer simulations, we show the dependence of the nucleus size and Young's modulus on the average mechanical properties of the cell.

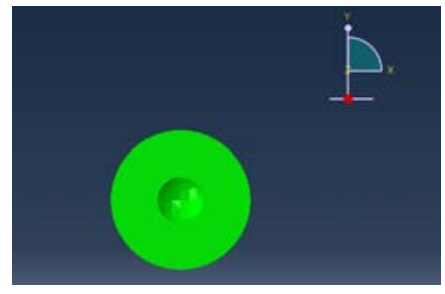

Figure 1 Undeformed cell

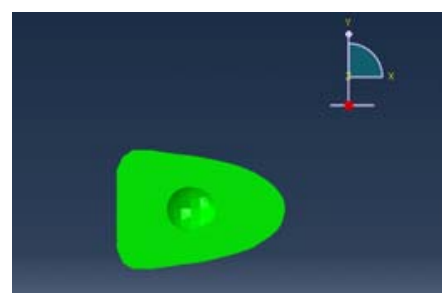

Figure 2 Deformed cell

\section{REFERENCES}

[1]. OTTO, O., ROSENDAHL, P., MIETKE, A., GOLFIER, S., HEROLD, C., KLAUE, D., GIRARDO, S., PAGLIARA, S., EKPINYONG, A., JACOBI, A., WOBUS, M., TÖPFNER, N., KEYSER, U., MANSFELD, J., FISCHER-FRIEDRICH, E., and GUCK, J. Real-time deformability cytometry: on-thefly cell mechanical phenotyping. En: Nature Methods. March 2015, vol.12, no.3, 199-202.

[2]. MIETKE, A., OTTO, O., GIRARDO, S., ROSENDAHL, P., TAUBENBERGER, A., GOLFIER, S., ULBRICHT, E., ALAND, S., GUCK, J., and FISCHER-FRIEDRICH, E. Extracting Cell Stifness from Real-time deformability cytometry: Theory and Experiment. En: Biophysical Journal. September 2015, 2023-2036. 